\title{
Cancel the denosumab holiday
}

\author{
M. R. McClung ${ }^{1}$
}

Received: 21 February 2016 / Accepted: 23 February 2016 / Published online: 1 March 2016

(C) International Osteoporosis Foundation and National Osteoporosis Foundation 2016

Denosumab, a fully human IgG2 anti-RANK ligand antibody, quickly and substantially inhibits bone remodeling [1]. As expected by the pharmacology of denosumab, this inhibition of remodeling is completely reversible upon stopping treatment [2]. In clinical trials, discontinuing therapy after 2 years results in a rapid rebound in bone turnover markers, raising concern about whether that high remodeling rate and consequent rapid bone loss that occurs has clinical relevance beyond a simple waning of the treatment benefit [3, 4]. Despite these concerns, many patients stop denosumab therapy, sometimes upon the advice of their physicians, especially in preparation for invasive dental procedures [5-7]. Three recent reports have described five patients in whom denosumab treatment was stopped because substantial gains on bone mineral density (BMD) had been achieved and who then experienced vertebral fractures within the first several months after discontinuing therapy. These cases re-focus our attention on the concern about a rebound in fracture risk and make it clear that a "holiday" from denosumab therapy is not justified in patients with osteoporosis [8-10].

It is well established that denosumab treatment of postmenopausal women with osteoporosis and of men and women receiving hormone ablation therapy for the management of prostate and breast cancer is associated with substantial (about $70 \%$ ) reduction in the risk of vertebral fracture [11-13]. In women with osteoporosis, hip fracture risk is reduced by $40 \%$ and non-vertebral fracture risk by $20 \%$, and efficacy may be sustained with long-term therapy [11, 14]. Progressive

\section{R. McClung}

mmcclung@orost.com

1 Oregon Osteoporosis Center, 2881 NW Cumberland Road, Portland, OR 97210, USA increases in bone mineral density (BMD) are observed with long-term therapy with increments from baseline of 18 and $8 \%$ observed in the lumbar spine and total hip region, respectively, after 8 years, and emerging evidence suggests that the proximal femur BMD achieved on therapy is a good indicator of an individual patient's risk of non-vertebral fracture $[14,15]$.

There are few reasons to stop denosumab therapy. Refractoriness to therapy has not been demonstrated. Intolerance is uncommon. Although rare cases of atypical femoral fracture have been described in patients who have received denosumab (most often in patients with a history of previous bisphosphonate use), there is no clear signal of any risk associated with the duration of therapy [16]. However, despite the favorable benefit risk profile, many-perhaps most - patients will discontinue therapy. In observational studies, persistence of 83-95\% after one year of denosumab therapy (meaning the patient received a second dose six months after their initial dose) and $68 \%$ at 24 months has been described [17-20]. Data regarding longer-term treatment or outside a clinical trial setting are not yet available. The usual reasons for discontinuing treatment exist (perceived intolerance or ineffectiveness, concerns about rare side effects, cost, etc.). In addition, physicians themselves may recommend that treatment be stopped after several years in patients whose BMD has increased sufficiently to move the patient above the threshold of osteoporosis and out of a high-risk category $[15,21]$.

The rebound in remodeling rates to values higher than pretreatment levels with rapid bone loss upon stopping denosumab is well documented. In the phase 2 study of Miller et al., follow-up after discontinuing denosumab treatment was available in 50 patients [3]. After two years of treatment with $210 \mathrm{mg}$ denosumab every 6 months or $30 \mathrm{mg}$ every 3 months, serum CTX levels increased to twice the placebo 
value at 6-12 months after stopping therapy and fell back to baseline two years after treatment was discontinued. The mechanism of the overshoot in bone resorption is not understood but could be due to an expanded pool of osteoclast precursors that are simultaneously activated or to a high RANK ligand/OPG ratio after denosumab is cleared from the circulation. BMD in the lumbar spine and total hip had increased, on average, by about 8 and $5 \%$, respectively, but fell back to or near baseline within one year of stopping therapy. Similar responses to treatment withdrawal, including an overshoot in remodeling markers and loss of the $6 \%$ gain in lumbar spine BMD within 1 year, were observed in the phase 3 prevention study in which women had received the clinical denosumab dose of $60 \mathrm{mg}$ every 6 months for 2 years [4].

The important clinical question is whether this interval of high turnover and rapid bone loss results in an abnormally high fracture risk - a rebound to a level of risk higher than just a return to the pre-treatment fracture status. That concern is based on evidence that fracture risk is directly related to bone turnover in untreated postmenopausal women who are losing bone mass at a modest rate [22]. There is also evidence that the rapid bone loss in early menopause is associated with more rapid destruction of trabecular microarchitecture than occurs in older postmenopausal women who are losing bone less rapidly [23]. That BMD values in individual patients returned to their own baseline value upon stopping denosumab suggests that the magnitude of bone loss may be related to the amount of BMD gain during treatment [3]. There is little information about the effects of withdrawal after longer-term denosumab treatment when BMD gains on therapy would be larger than those in the studies by Miller et al. and Bone et al. Preliminary evidence suggests that the loss of lumbar spine and total hip BMD is about the same (6-7 \% over 12 months) in women with low bone mass who had received denosumab for 8 years during which increases in the spine and hip BMD of 16.8 and $6.2 \%$ had occurred at the time treatment was stopped [24]. Unfortunately, these patients were not followed longer to determine whether the rapid bone loss continued during the subsequent year.

In the small groups of patients followed in clinical trials after discontinuation of denosumab, we have no evidence of a rebound in fracture risk. In the study by Miller et al., it was reported that there was no increase in fracture incidence in the small subgroup that stopped therapy, but the fracture rates were not provided [3]. In the low-risk population studied by Bone et al., clinical fractures occurred in eight of 256 patients during the two-year post-treatment observation [4]. Those fractures were evenly divided between patients who had received denosumab or placebo during the previous two years of active treatment. Brown and colleagues reported fracture incidence in 797 patients who discontinued denosumab or placebo in the phase 3 FREEDOM trial [25]. The average duration on therapy before patients discontinued was about 3.4 doses, or less than two years. Clinical fractures occurred after stopping therapy in 9 and $7 \%$ of patients who had received placebo or denosumab, respectively. The rate of vertebral fractures was lower (5.6 per 100 patient-years) in those who had taken denosumab compared to a rate of 9.3 in the previous placebo group. However, the median off-treatment interval was only eight months, and the maximum off-treatment interval was 24 months. Additionally, $28-42 \%$ of these patients had begun other osteoporosis treatments during their offtreatment follow-up.

Studies of the effects of discontinuing other osteoporosis drugs on fracture risk provide little insight. The unique skeletal retention of bisphosphonates results in a variable but slow rise in remodeling markers without rebound and without rapid bone loss as is observed when denosumab is withdrawn [26-29]. Upon stopping raloxifene, the very modest ontreatment effects of BMD and remodeling markers return to baseline within one year, and no fracture data were provided during the off-treatment interval [30].

The initial lumbar spine BMD response to teriparatide is at least as great as that seen with denosumab [31]. When teriparatide is stopped, bone loss occurs, but BMD does not, on average, return to baseline levels within 18 months of discontinuation, and a persistent effect on vertebral fracture risk was reported at the end of the 18 -month post-treatment follow-up [32]. However, the relative risk reduction reported at that time point $(41 \%$, CI $15-38)$ was clearly lower than the $65 \%$ risk reduction reported on treatment with $20 \mu \mathrm{g}$ teriparatide daily. This suggests that the protection from vertebral fracture had abated or had even reversed during the offtreatment interval. Unfortunately, since it is not possible to deduce the fracture incidence during the off-treatment interval from the study report, the question of whether a rebound in fracture risk occurred cannot be answered.

An exuberant increase in remodeling markers and rapid bone loss, reminiscent of the denosumab experience, was observed when odanacatib was discontinued after two years [33]. The increase in lumbar spine BMD (about $6 \%$ ) during two years of odanacatib therapy was similar to that reported by Miller et al. and by Bone et al. after two-year treatment with denosumab. The resolution of the high bone markers occurred more quickly after stopping odanacatib (normalized within 12 months) than denosumab (24 months). Thus, patients stopping odanacatib were exposed to a shorter interval of high bone turnover. The patients who discontinued odanacatib were followed for up to three years after stopping treatment, but the incidence of fracture in that small group of patients was not reported [34].

In contrast to the small studies evaluating responses to withdrawal of osteoporosis drugs, there are several, much larger studies evaluating the skeletal effects of stopping estrogen therapy in postmenopausal women. In such patients, estrogen use has been associated with preservation or 
improvement in bone mineral density and a reduction in fracture risk in both observational and randomized control trials [26, 27, 35-38]. When treatment is stopped after 2-10 years, relatively rapid bone loss occurs with lumbar spine BMD returning to levels observed in untreated women within 12 years [26, 27, 39-42]. This rate and amount of bone loss is similar to that observed in the denosumab discontinuation studies. Markers of bone turnover also quickly return to baseline or untreated levels upon stopping estrogen [26, 27, 42, 43]. In older postmenopausal women with osteoporosis, urinary NTX returned to the levels in untreated patients within three months after withdrawal of conjugated estrogen $0.625 \mathrm{mg}$ daily without evidence of rebound [26]. In contrast, when estrogen-progestin therapy was discontinued after four years in younger postmenopausal women without osteoporosis, urinary NTX increased to levels above that seen in untreated women, returning to the untreated levels two years after withdrawal, a pattern not unlike that observed upon stopping denosumab [27]. Unfortunately, fracture incidence after estrogen withdrawal was not reported in those studies.

In several observational studies, clinical fracture risk has been observed to increase as much as $50 \%$ in women who stopped estrogen therapy compared to those who continued $[44,45]$. Assuming that estrogen reduced fracture risk by about $1 / 3$, this $50 \%$ increase would put the risk back at pretreatment levels. In both Women's Health Initiative (WHI) studies, fracture protection noted on estrogen therapy was lost within 3-5 years of stopping estrogen therapy [46-48]. There was no evidence of a rebound in clinical fracture risk. This was most clearly shown in Figure 1 of the study by Heiss and colleagues [46]. During the first three years after withdrawal of estrogen-progestin therapy, the cumulative incidence plots of hip fracture were the same in women who had taken estrogen-progestin or placebo.

There are precedents of physiologic or biochemical rebounds upon stopping antihypertensive and anticoagulant therapy, resulting in higher risks of untoward clinical events $[49,50]$. We have too little evidence from clinical trials about discontinuing denosumab and other osteoporosis drugs to be confident that such a rebound in risk does not occur. Moreover, the lack of evidence of a rebound in fracture risk in the estrogen withdrawal studies should not be reassuring. The risk of vertebral fracture, the fracture observed in the five cases after stopping denosumab and the one most likely to occur in states of significant remodeling imbalance, was not assessed in the estrogen withdrawal studies. More importantly, none of the estrogen studies evaluated populations of women with osteoporosis who were at high risk for fracture before treatment. In such women, whose trabecular architecture may not be seriously impaired, rapid bone loss for 1-2 years would not significantly alter fracture risk, just as vertebral fracture risk does not increase substantially during the few years of relatively rapid spinal bone loss in early menopause. In contrast, four of the five reported cases with vertebral fractures upon denosumab withdrawal did have osteoporosis with lumbar spine T-score values ranging from -2.5 to -4 . 1 . In these women, whose vertebral microarchitecture was likely damaged prior to treatment, high turnover would increase the number and depth of stress risers on previously thinned trabeculae, leading to trabecular perforation and a sudden increase in fragility. That multiple vertebral fractures happened within 8-16 months after the last dose of denosumab makes this scenario very believable.

These five cases, of course, do not prove an association between stopping denosumab and a rebound in fracture risk, but they have put a clinical face on our concern, and they derail the concept of a "denosumab drug holiday." Obviously, we need more research and experience. However, unless or until more evidence teaches us differently, it is appropriate to act as if rebound in fracture risk upon stopping therapy is a real possibility, especially in patients with osteoporosis prior to therapy.

Fortunately, we have a simple treatment strategy that would likely prevent this remodeling rebound. Bisphosphonate therapy has consistently been shown to prevent bone loss in clinical situations of recent estrogen deficiency (menopause or beginning aromatase inhibitor therapy) [51-53]. More pertinently, alendronate prevented the bone loss that occurred when estrogen or parathyroid hormone therapy was discontinued [54, 55]. Alendronate also prevented bone loss upon stopping denosumab [56]. While not yet studied after withdrawal from denosumab, a single dose of intravenous zoledronic acid, known to inhibit bone turnover for up to five years, would very likely be effective in this setting $[57,58]$. For patients with osteoporosis who have received denosumab for 2 years or longer and who then stop therapy, whether it be in response to a perceived side effect or because they have reached their treatment "target," administering one dose of zoledronic acid to prevent the rapid bone loss seems like a very reasonable treatment strategy. Reassessment 1-2 years later would direct further management. For patients about to undergo an invasive dental procedure, there is no evidence that stopping denosumab therapy reduces the very low risk of osteonecrosis of the jaw. Rather than withholding therapy prior to and for some time after the oral surgical procedure, planning for the surgery to be performed 3-4 months after a denosumab dose would be preferable, allowing time for the oral lesions to heal before the next scheduled dose.

\section{Conclusion}

It is very plausible, given the rapid increase in bone remodeling and bone loss upon stopping denosumab, that a rebound increase in fracture risk ensues. So, until further notice, cancel the denosumab holiday. Interrupting therapy, even for a short 
time, runs the risk of not only discarding much or all of the benefit derived while on treatment but of exposing the patient to an unacceptable risk of vertebral fracture. Patients should be encouraged to continue denosumab therapy long term. If discontinuation does occur, appropriate steps must be taken to prevent the rapid bone loss and probable acute fracture risk.

Acknowledgments I thank Amy Roth of Providence Portland Medical Center Library for her help in obtaining many of the papers used in preparing this review.

\section{Compliance with ethical standards}

Conflicts of interest Dr. McClung has received consultation fees from Amgen and Merck.

Funding No funding was received in support of this manuscript.

\section{References}

1. Suresh E, Abrahamsen B (2015) Denosumab: a novel antiresorptive drug for osteoporosis. Cleve Clin J Med 82(2):105-114

2. Bekker PJ, Holloway DL, Rasmussen AS, Murphy R, Martin SW, Leese PT, Holmes GB, Dunstan CR, DePaoli AM (2004) A singledose placebo-controlled study of AMG 162, a fully human monoclonal antibody to RANKL, in postmenopausal women. J Bone Miner Res 19(12):1059-1066

3. Miller PD, Bolognese MA, Lewiecki EM, McClung MR, Ding B, Austin M, Liu Y, San MJ (2008) Effect of denosumab on bone density and turnover in postmenopausal women with low bone mass after long-term continued, discontinued, and restarting of therapy: a randomized blinded phase 2 clinical trial. Bone 43(2):222229

4. Bone HG, Bolognese MA, Yuen CK, Kendler DL, Miller PD, Yang YC, Grazette L, San Martin J, Gallagher JC (2011) Effects of denosumab treatment and discontinuation on bone mineral density and bone turnover markers in postmenopausal women with low bone mass. J Clin Endocrinol Metab 96(4):972-980

5. Slim L. Dental strategies for osteoporosis drugs. http://www. rdhmag.com/articles/print/volume-34/issue-8/columns/dentalstrategies-for-osteoporosis-drugs.html

6. Malan J, Ettinger K, Naumann E, Beirne OR (2012) The relationship of denosumab pharmacology and osteonecrosis of the jaws. Oral Surg Oral Med Oral Pathol Oral Radiol Endod 114(6):671676

7. O'Halloran M, Boyd NM, Smith A (2014) Denosumab and osteonecrosis of the jaws - the pharmacology, pathogenesis and a report of two cases. Aust Dent J 59(4):516-519

8. Aubry-Rozier B, Gonzalez-Rodriguez E, Stoll D, Lamy O (2015) Severe spontaneous vertebral fractures after denosumab discontinuation: three case reports. Osteoporos Int. doi:10.1007/s00198-0153380-y

9. Popp AW, Zysset PK, Lippuner K (2015) Rebound-associated vertebral fractures after discontinuation of denosumab-from clinic and biomechanics. Osteoporos Int. doi:10.1007/s00198-015-34586

10. Anastasilakis AD, Makras P (2015) Multiple clinical vertebral fractures following denosumab discontinuation. Osteoporos Int. doi:10. 1007/s00198-015-3459-5
11. Cummings SR, San Martin J, McClung MR, Siris ES, Eastell R, Reid IR, Delmas P, Zoog HB, Austin M, Wang A, Kutilek S, Adami S, Zanchetta J, Libanati C, Siddhanti S, Christiansen C (2009) Denosumab for prevention of fractures in postmenopausal women with osteoporosis. N Engl J Med 361(8):756-765

12. Smith MR, Egerdie B, Hernández Toriz N, Feldman R, Tammela TL, Saad F, Heracek J, Szwedowski M, Ke C, Kupic A, Leder BZ, Goessl C, Denosumab HALT Prostate Cancer Study Group (2009) Denosumab in men receiving androgen-deprivation therapy for prostate cancer. N Engl J Med 361(8):745-755

13. Gnant M, Pfeiler G, Dubsky PC, Hubalek M, Greil R, Jakesz R, Wette V, Balic M, Haslbauer F, Melbinger E, Bjelic-Radisic V, Artner-Matuschek S, Fitzal F, Marth C, Sevelda P, Mlineritsch B, Steger GG, Manfreda D, Exner R, Egle D, Bergh J, Kainberger F, Talbot S, Warner D, Fesl C, Singer CF, Austrian Breast and Colorectal Cancer Study Group (2015) Adjuvant denosumab in breast cancer (ABCSG-18): a multicentre, randomised, doubleblind, placebo-controlled trial. Lancet 386(9992):433-443

14. Papapoulos S, Lippuner K, Roux C, Lin CJ, Kendler DL, Lewiecki EM, Brandi ML, Czerwiński E, Franek E, Lakatos P, Mautalen C, Minisola S, Reginster JY, Jensen S, Daizadeh NS, Wang A, Gavin M, Libanati C, Wagman RB, Bone HG (2015) The effect of 8 or 5 years of denosumab treatment in postmenopausal women with osteoporosis: results from the FREEDOM Extension study. Osteoporos Int 26(12):2773-2783

15. Ferrari S, Adachi JD, Lippuner K, Zapalowski C, Miller PD, Reginster JY, Törring O, Kendler DL, Daizadeh NS, Wang A, O'Malley CD, Wagman RB, Libanati C, Lewiecki EM (2015) Further reductions in nonvertebral fracture rate with long-term denosumab treatment in the FREEDOM open-label extension and influence of hip bone mineral density after 3 years. Osteoporos Int 26(12):2763-2771

16. Lewiecki EM, Miller PD, Harris ST, Bauer DC, Davison KS, Dian L, Hanley DA, McClung MR, Yuen CK, Kendler DL (2014) Understanding and communicating the benefits and risks of denosumab, raloxifene, and teriparatide for the treatment of osteoporosis. J Clin Densitom 17(4):490-495

17. Silverman SL, Siris E, Kendler DL, Belazi D, Brown JP, Gold DT, Lewiecki EM, Papaioannou A, Simonelli C, Ferreira I, Balasubramanian A, Dakin P, Ho P, Siddhanti S, Stolshek B, Recknor C (2015) Persistence at 12 months with denosumab in postmenopausal women with osteoporosis: interim results from a prospective observational study. Osteoporos Int 26(1): 361-372

18. Papaioannou A, Khan A, Belanger A, Bensen W, Kendler D, Theoret F, Amin M, Brekke L, Erdmann M, Walker V, Adachi JD (2015) Persistence with denosumab therapy among osteoporotic women in the Canadian patient-support program. Curr Med Res Opin 31(7):1391-1401

19. Karlsson L, Lundkvist J, Psachoulia E, Intorcia M, Ström O (2015) Persistence with denosumab and persistence with oral bisphosphonates for the treatment of postmenopausal osteoporosis: a retrospective, observational study, and a meta-analysis. Osteoporos Int 26(10):2401-2411

20. Hadji P, Papaioannou N, Gielen E, Feudjo Tepie M, Zhang E, Frieling I, Geusens P, Makras P, Resch H, Möller G, KaloucheKhalil L, Fahrleitner-Pammer A (2015) Persistence, adherence, and medication-taking behavior in women with postmenopausal osteoporosis receiving denosumab in routine practice in Germany, Austria, Greece, and Belgium: 12-month results from a European non-interventional study. Osteoporos Int 26(10):2479-2489

21. Lewiecki EM, Cummings SR, Cosman F (2013) Treat-to-target for osteoporosis: is now the time? J Clin Endocrinol Metab 98(3):946953

22. Johansson H, Odén A, Kanis JA, McCloskey EV, Morris HA, Cooper C, Vasikaran S (2014) IFCC-IOF joint working group on 
standardisation of biochemical markers of bone turnover. A metaanalysis of reference markers of bone turnover for prediction of fracture. Calcif Tissue Int 94(5):560-567

23. Dufresne TE, Chmielewski PA, Manhart MD, Johnson TD, Borah B (2003) Risedronate preserves bone architecture in early postmenopausal women in 1 year as measured by three-dimensional microcomputed tomography. Calcif Tissue Int 73(5):423-432

24. McClung M, Lewiecki EM, Ho P-R, Michael Bolognese M, Wang A, Geller M, O'Malley C, Wagman RB, Miller P (2013) OR10-6: management trends after 8 years of denosumab: follow-up after a one-year observational phase of the phase 2 extension study. (abstract). Endo Society

25. Brown JP, Roux C, Törring O, Ho PR, Beck Jensen JE, Gilchrist N, Recknor C, Austin M, Wang A, Grauer A, Wagman RB (2013) Discontinuation of denosumab and associated fracture incidence: analysis from the fracture reduction evaluation of denosumab in osteoporosis every 6 months (FREEDOM) trial. J Bone Miner Res 28(4):746-752

26. Greenspan SL, Emkey RD, Bone HG, Weiss SR, Bell NH, Downs RW, McKeever C, Miller SS, Davidson M, Bolognese MA, Mulloy AL, Heyden N, Wu M, Kaur A, Lombardi A (2002) Significant differential effects of alendronate, estrogen, or combination therapy on the rate of bone loss after discontinuation of treatment of postmenopausal osteoporosis. A randomized, doubleblind, placebocontrolled trial. Ann Intern Med 137(11):875-883

27. Wasnich RD, Bagger YZ, Hosking DJ, McClung MR, Wu M, Mantz AM, Yates JJ, Ross PD, Alexandersen P, Ravn P, Christiansen C, Santora AC 2nd, Early Postmenopausal Intervention Cohort Study Group (2004) Changes in bone density and turnover after alendronate or estrogen withdrawal. Menopause 11(6 Pt 1):622-630

28. Bone HG, Hosking D, Devogelaer JP, Tucci JR, Emkey RD, Tonino RP, Rodriguez-Portales JA, Downs RW, Gupta J, Santora AC, Liberman UA, Alendronate Phase III Osteoporosis Treatment Study Group (2004) Ten years' experience with alendronate for osteoporosis in postmenopausal women. N Engl J Med 350(12): 1189-1199

29. Black DM, Reid IR, Boonen S, Bucci-Rechtweg C, Cauley JA, Cosman F, Cummings SR, Hue TF, Lippuner K, Lakatos P, Leung PC, Man Z, Martinez RL, Tan M, Ruzycky ME, Su G, Eastell R (2012) The effect of 3 versus 6 years of zoledronic acid treatment of osteoporosis: a randomized extension to the HORIZON-Pivotal Fracture Trial (PFT). J Bone Miner Res 27(2):243-254

30. Neele SJ, Evertz R, De Valk-De Roo G, Roos JC, Netelenbos JC (2002) Effect of 1 year of discontinuation of raloxifene or estrogen therapy on bone mineral density after 5 years of treatment in healthy postmenopausal women. Bone 30(4):599-603

31. Tsai JN, Uihlein AV, Lee H, Kumbhani R, Siwila-Sackman E, McKay EA, Burnett-Bowie SA, Neer RM, Leder BZ (2013) Teriparatide and denosumab, alone or combined, in women with postmenopausal osteoporosis: the DATA study randomised trial. Lancet 382(9886):50-56

32. Lindsay R, Scheele WH, Neer R, Pohl G, Adami S, Mautalen C, Reginster JY, Stepan JJ, Myers SL, Mitlak BH (2004) Sustained vertebral fracture risk reduction after withdrawal of teriparatide in postmenopausal women with osteoporosis. Arch Intern Med 164(9):2024-2030

33. Eisman JA, Bone HG, Hosking DJ, McClung MR, Reid IR, Rizzoli R, Resch H, Verbruggen N, Hustad CM, DaSilva C, Petrovic R, Santora AC, Ince BA, Lombardi A (2011) Odanacatib in the treatment of postmenopausal women with low bone mineral density: three-year continued therapy and resolution of effect. J Bone Miner Res 26(2):242-251

34. Langdahl B, Binkley N, Bone H, Gilchrist N, Resch H, Rodriguez Portales J, Denker A, Lombardi A, Le Bailly De Tilleghem C, Dasilva C, Rosenberg E, Leung A (2012) Odanacatib in the treatment of postmenopausal women with low bone mineral density: five years of continued therapy in a phase 2 study. J Bone Miner Res 27(11):2251-2258

35. The Writing Group for the PEPI Trial (1996) Effects of hormone therapy on bone mineral density: results from the postmenopausal estrogen/progestin interventions (PEPI) trial. JAMA 276(17):1389 1396

36. Cauley JA, Seeley DG, Ensrud K, Ettinger B, Black D, Cummings SR (1995) Estrogen replacement therapy and fractures in older women. Study of Osteoporotic Fractures Research Group. Ann Intern Med 122(1):9-16

37. Cauley JA, Robbins J, Chen Z, Cummings SR, Jackson RD, LaCroix AZ, LeBoff M, Lewis CE, McGowan J, Neuner J, Pettinger M, Stefanick ML, Wactawski-Wende J, Watts NB, Women's Health Initiative Investigators (2003) Effects of estrogen plus progestin on risk of fracture and bone mineral density: the Women's Health Initiative randomized trial. JAMA 290(13): $1729-1738$

38. Anderson GL, Limacher M, Assaf AR, Bassford T, Beresford SA, Black H, Bonds D, Brunner R, Brzyski R, Caan B, Chlebowski R, Curb D, Gass M, Hays J, Heiss G, Hendrix S, Howard BV, Hsia J, Hubbell A, Jackson R, Johnson KC, Judd H, Kotchen JM, Kuller L, LaCroix AZ, Lane D, Langer RD, Lasser N, Lewis CE, Manson J, Margolis K, Ockene J, O'Sullivan MJ, Phillips L, Prentice RL, Ritenbaugh C, Robbins J, Rossouw JE, Sarto G, Stefanick ML, Van Horn L, Wactawski-Wende J, Wallace R, Wassertheil-Smoller S, Women's Health Initiative Steering Committee (2004) Effects of conjugated equine estrogen in postmenopausal women with hysterectomy: the Women's Health Initiative randomized controlled trial. JAMA 291(14):1701-1712

39. Lindsay R, Hart DM, MacLean A, Clark AC, Kraszewski A, Garwood J (1978) Bone response to termination of oestrogen treatment. Lancet 1(8078):1325-1327

40. Christiansen C, Christiansen MS, Transbol I (1981) Bone mass in postmenopausal women after withdrawal of oestrogen/gestagen replacement therapy. Lancet 28(8228):459-461

41. Greendale GA, Espeland M, Slone S, Marcus R, Barrett-Connor E, PEPI Safety Follow-Up Study (PSFS) Investigators (2002) Bone mass response to discontinuation of long-term hormone replacement therapy: results from the postmenopausal estrogen/progestin interventions (PEPI) safety follow-up study. Arch Intern Med 162(6):665-672

42. Gallagher J, Rapuri PB, Haynatzki G, Detter JR (2002) Effect of discontinuation of estrogen, calcitriol, and the combination of both on bone density and bone markers. J Clin Endocrinol Metab 87(11): 4914-4923

43. Thomsen K, Riis BJ, Johansen JS, Christiansen C, Rødbro P (1987) Bone turnover in postmenopausal women after withdrawal of estrogen/gestagen replacement therapy. Gynecol Endocrinol 1(2): $169-175$

44. Banks E, Beral V, Reeves G, Balkwill A, Barnes I (2004) Fracture incidence in relation to the pattern of use of hormone therapy in postmenopausal women. JAMA 291(18):2212-2220

45. Karim R, Dell RM, Greene DF, Mack WJ, Gallagher JC, Hodis HN (2011) Hip fracture in postmenopausal women after cessation of hormone therapy: results from a prospective study in a large health management organization. Menopause 18(11):1172-1177

46. Heiss G, Wallace R, Anderson GL, Aragaki A, Beresford SA, Brzyski R, Chlebowski RT, Gass M, LaCroix A, Manson JE, Prentice RL, Rossouw J, Stefanick ML, WHI Investigators (2008) Health risks and benefits 3 years after stopping randomized treatment with estrogen and progestin. JAMA 299(9):1036-1045

47. LaCroix AZ, Chlebowski RT, Manson JE, Aragaki AK, Johnson KC, Martin L, Margolis KL, Stefanick ML, Brzyski R, Curb JD, Howard BV, Lewis CE, Wactawski-Wende J, Investigators WHI (2011) Health outcomes after stopping conjugated equine estrogens 
among postmenopausal women with prior hysterectomy: a randomized controlled trial. JAMA 305(13):1305-1314

48. Manson JE, Chlebowski RT, Stefanick ML, Aragaki AK, Rossouw JE, Prentice RL, Anderson G, Howard BV, Thomson CA, LaCroix AZ, Wactawski-Wende J, Jackson RD, Limacher M, Margolis KL, Wassertheil-Smoller S, Beresford SA, Cauley JA, Eaton CB, Gass M, Hsia J, Johnson KC, Kooperberg C, Kuller LH, Lewis CE, Liu S, Martin LW, Ockene JK, O’Sullivan MJ, Powell LH, Simon MS, Van Horn L, Vitolins MZ, Wallace RB (2013) Menopausal hormone therapy and health outcomes during the intervention and extended post-stopping phases of the Women's Health Initiative randomized trials. JAMA 310(13):1353-1368

49. Metz S, Klein C, Morton N (1987) Rebound hypertension after discontinuation of transdermal clonidine therapy. Am J Med 82(1):17-19

50. Diehl P, Halscheid C, Olivier C, Helbing T, Bode C, Moser M (2011) Discontinuation of long term clopidogrel therapy induces platelet rebound hyperaggregability between 2 and 6 weeks post cessation. Clin Res Cardiol 100(9):765-771

51. McClung M, Clemmesen B, Daifotis A, Gilchrist NL, Eisman J, Weinstein RS, Fuleihan GEH, Reda C, Yates AJ, Ravn P, Alendronate Osteoporosis Prevention Study Group (1998) Alendronate prevents postmenopausal bone loss in women without osteoporosis. A double-blind, randomized, controlled trial. Ann Intern Med 128(4):253-261

52. Greenspan SL, Vujevich KT, Brufsky A, Lembersky BC, van Londen GJ, Jankowitz RC, Puhalla SL, Rastogi P, Perera S (2015) Prevention of bone loss with risedronate in breast cancer survivors: a randomized, controlled clinical trial. Osteoporos Int 26(6):1857-1864
53. Wagner-Johnston ND, Sloan JA, Liu H, Kearns AE, Hines SL, Puttabasavaiah S, Dakhil SR, Lafky JM, Perez EA, Loprinzi CL (2015) 5-year follow-up of a randomized controlled trial of immediate versus delayed zoledronic acid for the prevention of bone loss in postmenopausal women with breast cancer starting letrozole after tamoxifen: N03CC (Alliance) trial. Cancer 121(15):2537-2543

54. Rittmaster RS, Bolognese M, Ettinger MP, Hanley DA, Hodsman AB, Kendler DL, Rosen CJ (2000) Enhancement of bone mass in osteoporotic women with parathyroid hormone followed by alendronate. J Clin Endocrinol Metab 85(6):2129-2134

55. Ascott-Evans BH, Guanabens N, Kivinen S, Stuckey BG, Magaril $\mathrm{CH}$, Vandormael K, Stych B, Melton ME (2003) Alendronate prevents loss of bone density associated with discontinuation of hormone replacement therapy: a randomized controlled trial. Arch Intern Med 163(7):789-794

56. Freemantle N, Satram-Hoang S, Tang ET, Kaur P, Macarios D, Siddhanti S, Borenstein J, Kendler DL, DAPS Investigators (2012) Final results of the DAPS (denosumab adherence preference satisfaction) study: a 24-month, randomized, crossover comparison with alendronate in postmenopausal women. Osteoporos Int 23(1): 317-326

57. McClung M, Miller P, Recknor C, Mesenbrink P, Bucci-Rechtweg C, Benhamou CL (2009) Zoledronic acid for the prevention of bone loss in postmenopausal women with low bone mass: a randomized controlled trial. Obstet Gynecol 114(5):999-1007

58. Grey A, Bolland MJ, Horne A, Wattie D, House M, Gamble G, Reid IR (2012) Five years of anti-resorptive activity after a single dose of zoledronate - results from a randomized double-blind placebo-controlled trial. Bone 50(6):1389-1393 